\title{
Flavihumibacter petaseus gen. nov., sp. nov., isolated from soil of a subtropical rainforest
}

Correspondence

Hong Li Yuan

hlyuan@cau.edu.cn

\author{
Nan Nan Zhang, Jian Hang Qu, Hong Li Yuan, Yan Mei Sun \\ and Jin Shui Yang
}

State Key Lab for Agrobiotechnology, Key Laboratory of Agro-Microbial Resource and Application, College of Biological Sciences, China Agricultural University, Beijing 100193, PR China

\begin{abstract}
A yellow-coloured bacterium, $\mathrm{T} 41^{\top}$, was isolated from a soil sample of a subtropical rainforest in Nepal. Cells were Gram-reaction-positive, aerobic, non-motile, short rods. Phylogenetic analysis based on 16S rRNA gene sequences indicated that the strain formed a cluster with Terrimonas ferruginea, Terrimonas lutea, Niabella soli, Flavisolibacter ginsengiterrae, Flavisolibacter ginsengisoli, Niastella yeongjuensis and Niastella koreensis in the phylum Bacteroidetes. The strain showed the highest sequence similarity to the type strain of Terrimonas lutea (93.2\%). The major isoprenoid quinone was MK-7 and the predominant cellular fatty acids $(>10 \%)$ were iso$15: 0(33.8 \%)$, iso-15: $1 \mathrm{G}(13.3 \%)$ and iso-17:0 3-OH (12.9\%). The DNA G + C content was $48.1 \mathrm{~mol} \%$. On the basis of phenotypic and phylogenetic data and genomic distinctiveness, strain $\mathrm{T} 41^{\top}$ represents a novel species in a new genus in the phylum Bacteroidetes, for which the name Flavihumibacter petaseus gen. nov., sp. nov. is proposed. The type strain of Flavihumibacter petaseus is strain $\mathrm{T} 41^{\top}\left(=\mathrm{CGMCC} 1.7723^{\top}=\operatorname{NBRC} 106054^{\top}\right)$.
\end{abstract}

During the course of a study on the culturable bacterial community in a subtropical rainforest soil sample from Nepal $\left(27^{\circ} 34^{\prime} \mathrm{N} 84^{\circ} 31^{\prime} \mathrm{E}\right)$, a novel yellow-pigmented bacterium, designated strain $\mathrm{T} 41^{\mathrm{T}}$, was isolated. On the basis of phylogenetic analysis, strain $\mathrm{T} 41^{\mathrm{T}}$ formed a distinct cluster closely related to members of the genera Terrimonas, Flavisolibacter, Niabella and Niastella of the phylum Bacteroidetes. The polyphasic phenotypic and genotypic characterization of strain $\mathrm{T} 41^{\mathrm{T}}$ is described in this report.

The soil sample was serially diluted with $0.85 \% \mathrm{NaCl}(\mathrm{w} / \mathrm{v})$ and the dilutions were plated onto modified R2A agar containing $\left(1^{-1}\right) 0.5 \mathrm{~g}$ glucose, $0.5 \mathrm{~g}$ casein hydrolysate, $0.5 \mathrm{~g}$ soluble starch, $0.5 \mathrm{~g}$ peptone, $0.5 \mathrm{~g}$ yeast extract, $0.3 \mathrm{~g}$ $\mathrm{K}_{2} \mathrm{HPO}_{4}, 0.05 \mathrm{~g} \mathrm{MgSO}_{4} .7 \mathrm{H}_{2} \mathrm{O}$ and $17 \mathrm{~g}$ agar ( $\mathrm{pH}$ 7.2). The plates were incubated at $28{ }^{\circ} \mathrm{C}$ for 7 days. Single colonies were purified by transferring them onto new R2A plates and were incubated once again. Purified colonies were maintained as glycerol suspensions $(20 \%$, w/v) at $-70{ }^{\circ} \mathrm{C}$.

The Gram reaction was determined using the non-staining method, as described by Buck (1982). Cell morphology was observed under a light microscope (Nikon) at $\times 1000$, with

The GenBank/EMBL/DDBJ accession number for the $16 \mathrm{~S}$ rRNA gene sequence of strain $T 41^{\top}$ is EU854577.

$16 \mathrm{~S}$ rRNA gene sequence-based maximum-parsimony and minimumevolution phylogenetic trees are available as supplementary material with the online version of this paper. cells grown for 3 days at $28{ }^{\circ} \mathrm{C}$ on $\mathrm{R} 2 \mathrm{~A}$ agar. Motility was examined using the hanging-drop technique with fresh cells in R2A broth. Catalase activity was determined by bubble production in $3 \%(\mathrm{v} / \mathrm{v}) \mathrm{H}_{2} \mathrm{O}_{2}$, and oxidase activity was determined by daubing cultures with $1 \%(\mathrm{w} / \mathrm{v}) \mathrm{N}, \mathrm{N}-$ dimethyl p-phenylenediamine (Yoon \& Im, 2007). Carbonsource utilization was assessed using a liquid medium containing $\left(\mathrm{l}^{-1}\right) 1 \mathrm{~g}\left(\mathrm{NH}_{4}\right)_{2} \mathrm{HPO}_{4}, 0.3 \mathrm{~g} \mathrm{~K}_{2} \mathrm{HPO}_{4}, 0.05 \mathrm{~g}$ $\mathrm{MgSO}_{4} \cdot 7 \mathrm{H}_{2} \mathrm{O}$ and $0.2 \mathrm{~g}$ yeast extract ( $\mathrm{pH} 7.2$ ). Carbon substrates were added at a concentration of $0.5 \%(\mathrm{w} / \mathrm{v})$. The culture was incubated under $28{ }^{\circ} \mathrm{C}$ and, after 3 days, the result was compared using a spectrophotometer. Acid production was investigated by adding bromothymol blue as an indicator after 3 days of incubation. Growth at 4, 20, 28,37 and $50{ }^{\circ} \mathrm{C}$ and $\mathrm{pH} 5.0-10.0$ (in intervals of $0.5 \mathrm{pH}$ units) was assessed after 5 days of incubation. Salt tolerance was tested on R2A broth supplemented with 0 , $0.5,1,1.5,2,3$ and $5 \%(\mathrm{w} / \mathrm{v}) \mathrm{NaCl}$. Nitrate reduction and degradation of casein, gelatin, urea, DNA and starch were examined according to the method of Dong \& Cai (2001).

For the measurement of the $\mathrm{G}+\mathrm{C}$ content of chromosomal DNA, genomic DNA was extracted and purified as described by Marmur (1961). The G+C content was determined by the thermal denaturation method using a BIO-20 UV spectrophotometer as described by De Ley (1970). For the analysis of isoprenoid quinones, cells grown aerobically were freeze-dried and subjected to extraction of the lipid fraction as described by Collins (1985). Fatty acid methyl esters were prepared and extracted from cells grown on $\mathrm{R} 2 \mathrm{~A}$ medium for $48 \mathrm{~h}$ at $28{ }^{\circ} \mathrm{C}$, following the standard 
protocol of the Microbial Identification System (MIDI, 1999).

PCR-mediated amplification of the 16S rRNA gene was carried out according to Güssow \& Clackson (1989). The primers used were Eub27f and Eub1495r (Di Cello et al., 1997). The $16 \mathrm{~S}$ rRNA gene sequences of related taxa were obtained from GenBank. Multiple alignments were performed with CLUSTAL_X (Thompson et al., 1997). Phylogenetic and molecular evolutionary analyses were conducted using the MEGA 3.1 (Kumar et al., 2004) software package and clustering was determined using the neighbourjoining (Saitou \& Nei, 1987), maximum-parsimony (Fitch, 1971) and minimum-evolution (Rzhetsky \& Nei, 1992) algorithms with bootstrap values based on 1000 replications (Felsenstein, 1985), in order to determine the stability of clusters.

Cells of strain $\mathrm{T} 41^{\mathrm{T}}$ were aerobic, Gram-reactionpositive, non-motile, short rods. When grown on R2A agar plates for 3 days, the colonies were smooth, circular, yellow and 1-2 $\mathrm{mm}$ in diameter. On R2A agar medium, strain $\mathrm{T} 41^{\mathrm{T}}$ grew at $20-37{ }^{\circ} \mathrm{C}$ and at $\mathrm{pH} 5.5-$ 9.5, with optimal growth at $28{ }^{\circ} \mathrm{C}$ and $\mathrm{pH} 6.5 . \mathrm{NaCl}$ was tolerated at $0-1.0 \%(\mathrm{w} / \mathrm{v})$. Other phenotypic and chemotaxonomic characteristics that differentiate strain
$\mathrm{T} 41^{\mathrm{T}}$ from its close phylogenetic relatives are shown in Table 1.

An almost-complete 16S rRNA gene sequence (1354 bp) for strain $\mathrm{T} 41^{\mathrm{T}}$ was determined and subjected to a phylogenetic analysis. Results showed that strain $\mathrm{T} 41^{\mathrm{T}}$ was clustered with the genera Terrimonas, Flavisolibacter, Niastella and Niabella in the phylum Bacteroidetes but was clearly separated from them (Fig. 1 and Supplementary Figs S1 and S2, available in IJSEM Online). Isolate $\mathrm{T} 41^{\mathrm{T}}$ showed the highest levels of 16S rRNA gene sequence similarity to type strains of the genus Terrimonas (92.3$93.2 \%)$, followed by Flavisolibacter (92.1-92.2\%) and Niabella (91.2-91.7\%). The 16S rRNA gene sequence divergence of more than $3 \%$ may place $\mathrm{T} 41^{\mathrm{T}}$ in a novel genus and species (Stackebrandt \& Goebel, 1994).

The DNA G+C content of strain $\mathrm{T}_{4} 1^{\mathrm{T}}$ was $48.1 \mathrm{~mol} \%$. The major isoprenoid quinone was MK-7, as in the related species Terrimonas ferruginea, Terrimonas lutea, Flavisolibacter ginsengiterrae, Flavisolibacter ginsengisoli, Niabella soli, Niastella yeongjuensis and Niastella koreensis (Xie \& Yokota, 2006; Yoon \& Im, 2007; Weon et al., 2006, 2008). The major fatty acids $(>10 \%)$ were iso-15:0 (33.8\%), iso- $15: 1 \mathrm{G}(13.3 \%)$ and iso- $17: 03-\mathrm{OH}(12.9 \%)$ (Table 2). The presence of 15:0 and iso-15:1 G and some

Table 1. Phenotypic characteristics of strain $\mathrm{T} 41^{\top}$ and related type strains

Strains: $1, \mathrm{~T}_{4} 1^{\mathrm{T}} ; 2$, Terrimonas ferruginea ATCC $13524^{\mathrm{T}} ; 3$, Terrimonas lutea IAM $15284^{\mathrm{T}} ; 4$, Flavisolibacter ginsengiterrae DSM $18136^{\mathrm{T}}$; 5 , Flavisolibacter ginsengisoli DSM $18119^{\mathrm{T}} ; 6$, Niabella soli DSM $19437^{\mathrm{T}} ; 7$, Niastella yeongjuensis KACC $11466^{\mathrm{T}}$; 8, Niastella koreensis KACC $11465^{\mathrm{T}}$. Data for reference strains were taken from Xie \& Yokota (2006), Yoon \& Im (2007) and Weon et al. (2006, 2008). +, Positive; -, negative; w, weak reaction; ND, no data available.

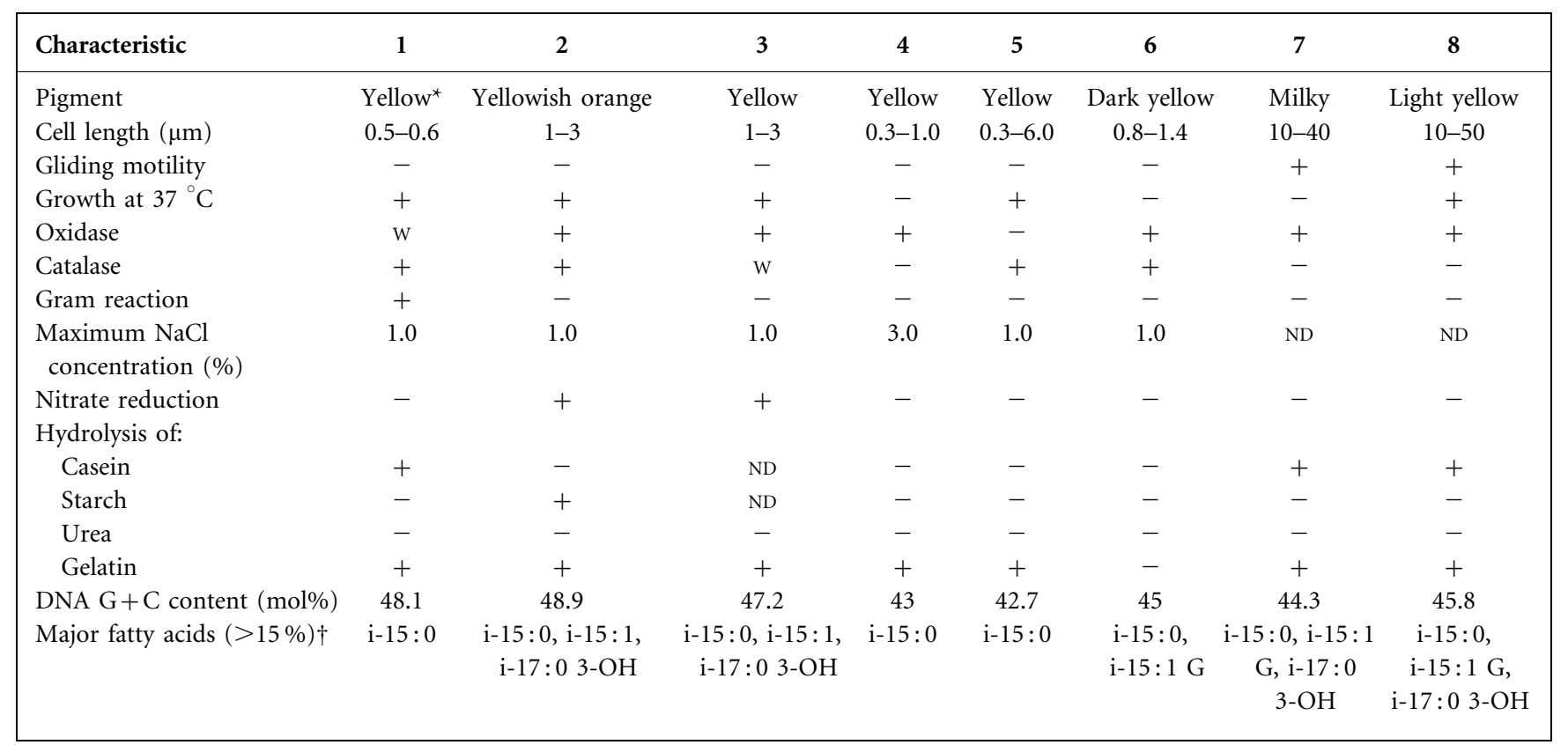

${ }^{\star}$ Pigment was observed on R2A culture plates.

$\dagger \mathrm{i}$, Iso-branched. 


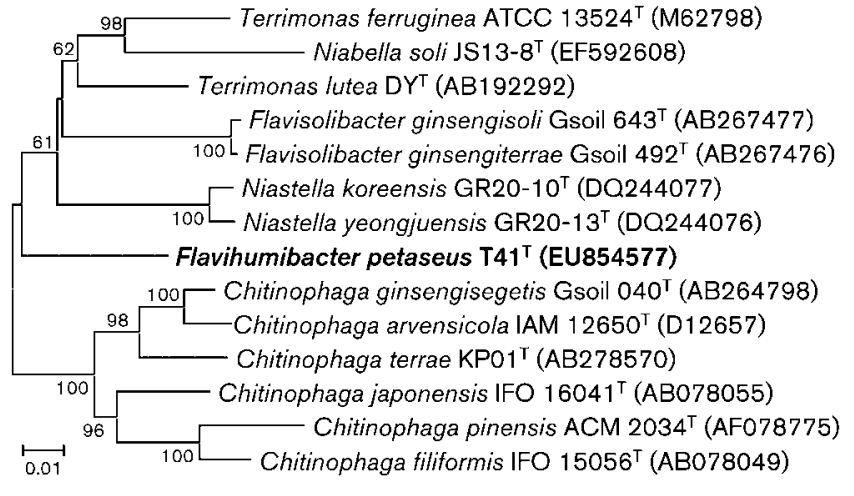

Fig. 1. Neighbour-joining phylogenetic tree based on the $16 \mathrm{~S}$ rRNA gene sequences of strain $\mathrm{T} 41^{\top}$ and related species. Bootstrap values are shown as percentages of 1000 replicates; values below $50 \%$ are not indicated. Bar, 1 substitution per 100 nucleotide positions.

Table 2. Cellular fatty acid composition of strain $\mathrm{T} 41^{\top}$ and related type strains

Strains: 1, T41 ${ }^{\mathrm{T}} ; 2$, Terrimonas ferruginea ATCC $13524^{\mathrm{T}} ; 3$, Terrimonas lutea IAM $15284^{\mathrm{T}}$; 4, Flavisolibacter ginsengiterrae DSM $18136^{\mathrm{T}} ; 5$, Flavisolibacter ginsengisoli DSM $18119^{\mathrm{T}} ; 6$, Niabella soli DSM $19437^{\mathrm{T}} ; 7$, Niastella yeongjuensis KACC $11466^{\mathrm{T}} ; 8$, Niastella koreensis KACC $11465^{\mathrm{T}}$. Data for reference strains were taken from Xie \& Yokota (2006), Yoon \& Im (2007) and Weon et al. (2006, 2008). Values are percentages of total fatty acids; fatty acids that account for $<1.0 \%$ of the total are not shown. -, Not reported or $<1 \%$.

\begin{tabular}{|lcccccccc|}
\hline Fatty acid & $\mathbf{1}$ & $\mathbf{2}$ & $\mathbf{3}$ & $\mathbf{4}$ & $\mathbf{5}$ & $\mathbf{6}$ & $\mathbf{7}$ & $\mathbf{8}$ \\
\hline iso-15:1 G & 13.3 & - & - & - & - & 18.4 & 14.7 & 15.6 \\
iso-15:0 & 33.8 & 28.4 & 34.8 & 45.9 & 31.2 & 29.2 & 30.6 & 26.8 \\
anteiso-15:0 & - & - & - & 5.9 & 5.0 & 1.2 & 3.3 & 4.9 \\
$15: 0$ & 8.0 & 2.7 & - & - & - & - & - & - \\
iso-16:0 & - & 1.4 & - & - & - & - & - & 1.0 \\
$16: 1 \omega 5 c$ & 5.8 & - & - & - & - & - & 1.2 & - \\
$16: 0$ & 2.2 & 1.7 & 1.1 & 5.5 & 7.5 & 6.8 & 2.9 & 2.6 \\
iso-15:0 3-OH & 3.9 & 2.2 & 2.3 & 1.4 & 1.0 & 2.2 & 1.9 & 1.3 \\
iso-17:0 & - & - & - & 3.1 & 9.1 & - & - & 1.6 \\
$16: 02-\mathrm{OH}$ & - & - & - & - & 2.9 & 1.3 & - & - \\
$16: 03-\mathrm{OH}$ & 2.7 & 2.5 & 3.3 & - & - & 2.2 & 2.3 & 1.3 \\
$18: 0$ & - & - & - & - & 2.0 & 3.8 & - & - \\
iso-17:0 3-OH & 12.9 & 15.3 & 14.2 & 13.7 & 11.8 & 11.8 & 27.1 & 29.4 \\
$17: 03-\mathrm{OH}$ & 1.1 & - & - & - & - & - & - & 1.2 \\
Summed & 8.3 & 11.2 & 14.9 & - & - & 11.1 & 5.3 & 4.3 \\
feature 3* & & & & & & & & \\
Unknown & 1.5 & 1.3 & 3.2 & - & - & 1.1 & - & - \\
13.565 & & & & & & & & \\
Unknown & - & 1.3 & 1.8 & - & - & - & 1.6 & 1.4 \\
16.582 & & & & & & & & \\
\hline
\end{tabular}

${ }^{\star}$ Summed feature 3 comprises iso-15:0 $2-\mathrm{OH}$ and/or $16: 1 \omega 7 c$. quantitative differences in fatty acid composition distinguish isolate $\mathrm{T} 41^{\mathrm{T}}$ from phylogenetically related genera.

On the basis of the observations described above, it is appropriate to conclude that strain $\mathrm{T} 41^{\mathrm{T}}$ represents a novel species in a new genus, for which the name Flavihumibacter petaseus gen. nov., sp. nov. is proposed.

\section{Description of Flavihumibacter gen. nov.}

Flavihumibacter (Fla'vi.hu.mi.bac'ter. L. adj. flavus yellow; L. n. humus soil; L. masc. n. bacter a rod; N.L. masc. n. Flavihumibacter a yellow, rod-shaped bacterium from soil).

Cells are Gram-reaction-positive, aerobic, single rods. Positive for catalase and weakly positive for oxidase. The major fatty acids $(>10 \%)$ are iso-15:0, iso-15:1 G and iso-17:0 3-OH. The major respiratory quinone is MK-7. The genus is positioned phylogenetically within the phylum Bacteroidetes. The type species is Flavihumibacter petaseus.

\section{Description of Flavihumibacter petaseus sp. nov.}

Flavihumibacter petaseus (pe.ta'se.us. L. n. petasus hat; L. adj. suff. -eus -ea -eum suffix used with various meanings; N.L. masc. adj. petaseus belonging to a hat, referring to the formation of hat-shaped colonies).

Possesses the following properties in addition to those given in the genus description. Cells are $0.4-0.5 \mu \mathrm{m}$ wide and $0.5-0.6 \mu \mathrm{m}$ long, without gliding motility. Colonies grown on R2A agar plates are circular, smooth, yellow and $1-2 \mathrm{~mm}$ in diameter. Growth occurs at $20-37{ }^{\circ} \mathrm{C}$ and $\mathrm{pH}$ 5.5-9.5, with optimum growth at $28{ }^{\circ} \mathrm{C}$ and $\mathrm{pH} 6.5$. Growth is inhibited by $>1.0 \% \mathrm{NaCl}$. Maltose, sucrose, L-rhamnose, starch, D-fructose, trehalose, D-galactose, Dxylose, melibiose, D-arabinose, salicin, raffinose, glucose, $\mathrm{D}$-mannose, lactose and L-arabinose are assimilated, but mannitol, D-sorbitol, inulin, inositol, sodium D-gluconate, melezitose, sorbose, D-ribose, cellobiose and glycerol are not. Acid is produced from maltose, sucrose, L-rhamnose, starch, D-fructose, trehalose, D-galactose, D-xylose, melibiose, D-arabinose, salicin, glucose, D-mannose, lactose and L-arabinose. Negative reactions are observed for lipase, urease production, nitrate reduction, nitrite reduction, denitrification and hydrolysis of lecithin, arginine, starch and DNA. Positive for $\mathrm{H}_{2} \mathrm{~S}$ production and hydrolysis of casein and gelatin. The $\mathrm{G}+\mathrm{C}$ content of the DNA of the type strain is $48.1 \mathrm{~mol} \%$.

The type strain is $\mathrm{T}_{4} 1^{\mathrm{T}}$ (=CGMCC $1.7723^{\mathrm{T}}=\mathrm{NBRC}$ $\left.106054^{\mathrm{T}}\right)$, which was isolated from a soil sample from a subtropical rainforest in Nepal.

\section{Acknowledgements}

This work was supported by a grant (no. 30670071) from the Chinese National Natural Science Foundation, the Hi-tech Research and Development Program (863 Program) of China (no. 2006AA10A213) and the National Basic Research (973) program of China (project no. 
2006CB100206). We are indebted to Dr Jean Euzéby (Ecole Nationale Vétérinaire, Toulouse, France) for his kind assistance in Latin nomenclature.

\section{References}

Buck, J. D. (1982). Nonstaining ( $\mathrm{KOH})$ method for determination of Gram reactions of marine bacteria. Appl Environ Microbiol 44, 992993.

Collins, M. D. (1985). Isoprenoid quinone analysis in classification and identification. In Chemical Methods in Bacterial Systematics, pp. 267-287. Edited by M. Goodfellow \& D. E. Minnikin. London: Academic Press.

De Ley, J. (1970). Reexamination of the association between melting point, buoyant density, and chemical base composition of deoxyribonucleic acid. J Bacteriol 101, 737-754.

Di Cello, F., Bevivino, A., Chiarini, L., Fani, R., Paffetti, D., Tabacchioni, S. \& Dalmastri, C. (1997). Biodiversity of a Burkholderia cepacia population isolated from the maize rhizosphere at different plant growth stages. Appl Environ Microbiol 63, 4485-4493.

Dong, X. Z. \& Cai, M. Y. (2001). General Bacterial Identification System Handbook, pp. 377-385. Beijing: Scientific Press.

Felsenstein, J. (1985). Confidence limits on phylogenies: an approach using the bootstrap. Evolution 39, 783-791.

Fitch, W. M. (1971). Toward defining the course of evolution: minimum change for a specific tree topology. Syst Zool 20, 406-416.

Güssow, D. \& Clackson, T. (1989). Direct clone characterization from plaques and colonies by the polymerase chain reaction. Nucleic Acids Res 17, 4000.

Kumar, S., Tamura, K. \& Nei, M. (2004). MEGA3: integrated software for molecular evolutionary genetics analysis and sequence alignment. Brief Bioinform 5, 150-163.
Marmur, J. (1961). A procedure for the isolation of deoxyribonucleic acid from microorganisms. J Mol Biol 3, 208-218.

MIDI (1999). Sherlock Microbial Identification System, Operating Manual, version 3.0. Newark, DE: MIDI, Inc.

Rzhetsky, A. \& Nei, M. (1992). A simple method for estimating and testing minimum evolution trees. Mol Biol Evol 9, 945-967.

Saitou, N. \& Nei, M. (1987). The neighbor-joining method: a new method for reconstructing phylogenetic trees. Mol Biol Evol 4, 406425.

Stackebrandt, E. \& Goebel, B. M. (1994). Taxonomic note: a place for DNA-DNA reassociation and $16 \mathrm{~S}$ rRNA sequence analysis in the present species definition in bacteriology. Int J Syst Bacteriol 44, 846849.

Thompson, J. D., Gibson, T. J., Plewniak, F., Jeanmougin, F. \& Higgins, D. G. (1997). The CLUSTAL_X windows interface: flexible strategies for multiple sequence alignment aided by quality analysis tools. Nucleic Acids Res 25, 4876-4882.

Weon, H.-Y., Kim, B.-Y., Yoo, S.-H., Lee, S.-Y., Kwon, S.-W., Go, S.-J. \& Stackebrandt, E. (2006). Niastella koreensis gen. nov., sp. nov. and Niastella yeongjuensis sp. nov., novel members of the phylum Bacteroidetes, isolated from soil cultivated with Korean ginseng. Int J Syst Evol Microbiol 56, 1777-1782.

Weon, H.-Y., Kim, B.-Y., Joa, J.-H., Kwon, S.-W., Kim, W.-G. \& Koo, B.-G. (2008). Niabella soli sp. nov., isolated from soil from Jeju Island, Korea. Int J Syst Evol Microbiol 58, 467-469.

Xie, C. H. \& Yokota, A. (2006). Reclassification of [Flavobacterium] ferrugineum as Terrimonas ferruginea gen. nov., comb. nov., and description of Terrimonas lutea sp. nov., isolated from soil. Int J Syst Evol Microbiol 56, 1117-1121.

Yoon, M. H. \& Im, W. T. (2007). Flavisolibacter ginsengiterrae gen. nov., sp. nov. and Flavisolibacter ginsengisoli sp. nov., isolated from ginseng cultivating soil. Int J Syst Evol Microbiol 57, 1834-1839. 